\author{
M.M. Kustaubayeva ${ }^{1}$, K.I. Samoilov ${ }^{2}$, B.T. Balykbaev ${ }^{3}$ \\ ${ }^{1}$ Bachelor of Arts (Architecture), «Architecture» Department post graduate \\ student, Satbayev University, ${ }^{2}$ Doctor of sciences (Architecture), «Architecture» \\ Department professor, Satbayev University, ${ }^{3}$ Candidate (Architecture, \\ «Architecture»
}

Department associate professor, Satbayev University, Almaty, Kazakhstan

\title{
FORMATION OF BARRIER-FREE PEDESTRIAN LINKS
}

Annotation. This article discusses the principles of creating a barrier-free urban environment for all people, including people limited in physical movement, determining the features and nature of the equipment of urban spaces and stay in the urban environment.

Key words: barrier-free environment, accessible environment, people with disabilities, urban environment, living environment.

The principle of «frame on frame» means «barrier-free corridors» in the existing communication structure of the city. This principle is that it allows you to calculate and provide information on how they can help people in the health sector.

With an existing system of these routes, you can demonstrate their impact. The most common is:

a. The existing development of vertical location in problematic situations in the natural landscape does not cause accessibility.

b. Most existing walking routes have intersections with traffic flows at the same level and are not specially equipped for people with disabilities.

c. Pedestrian corridors leading to maintenance and trade facilities are generally long, due to problematic situations that impede development and do not meet the parametric characteristics of the path itself with barrier-free requirements [1].

The principle of creating a barrier-free pedestrian connection «frame on frame» implies three main stages of design. It should be noted that this step-by-step work is not possible without a preliminary analysis of the estimated area:

Public buildings and structures and associated areas;

- Residential areas and related infrastructure;

- recreational inner-city spaces and expected exits to external recreation.

The first stage of creating barrier-free pedestrian routes on the basis of the «frame on the frame» principle is the identification of existing sidewalks with the indication of all possible problematic situations on them. It is also recommended to provide excellent places for people with disabilities. At the same time, marshals are based on publicly distributed bulbs and pseudonyms, mandatory differences within a quarter are the boundaries between functional and spatial units of residential areas; comprehensive - access to public buildings and structures [8].

Existing recreation areas are considered hiking route nodes. At this stage, the places of the so-called «Problem» rest are areas potentially intended for citizens to rest, which, however, are not adapted for this purpose and are not equipped. Areas 
with difficult access to recreation are also registered. In the city, these approaches are often hindered by the intersection of pedestrian routes with railways and industrial areas.

The first stage of creating barrier-free urban space on the basis of the principle of «frame on frame», thus determines the list of problem situations on existing urban pedestrian routes.

The second stage of the evaluated principle is the creation of an «ideal basis» for barrier-free walking routes for this area.

«The ideal frame is a pedestrian model with no design limitations. Limitations of spatial planning in this case are objective obstacles created by existing buildings and complexes for various purposes - residential, administrative, industrial preventing pedestrians from moving along the straight road «Ideal model» frame implies the presence of «destination nodes» of the pedestrian route, that is, objects that are most attractive for people with disabilities. These include not only elements of the medical and social system, but also recreation and entertainment centers, cultural services, trade and religious facilities [9]. Ideally, the main requirements for hiking trails are:

a. Lowest range;

b. Isolation from noise and pollution sources;

c. Full alignment of route parameters with ergonomic characteristics of older persons and persons with disabilities;

d. With a long route length on the «ideal frame» there are eight recreational modules designed for short-term rest.

The development of the second stage of barrier-free walking routes based on «frame-by-frame» should fully comply with the concept of a «theoretical model of barrier-free urban space for society for all mobility groups» at the city level described above.

The third last stage is a combination of the first and second stages, that is, a complex combination of existing and required conditions. A compromise solution at this stage is possible in some cases by applying urban planning methods to create a barrier-free environment.

This principle is applied as a result of the development of the «frame on the frame». At this stage, the location of the machine system and its composition will be determined by urban transport on the proposed basis of barrier-free connections. Thus, the corresponding technical equipment on barrier-free routes can be combined into several main systems [2]. All of these systems combine to provide the main characteristics of the environment: accessibility, comfort and safety. These groups are divided into:

Means of ensuring the comfort of transport, including transport itself, means ensuring the boarding and boarding process, the conditions for the use of passenger transport, the designation of parking spaces and parking for cars with disabilities.

The creation of transport services for people with reduced mobility is a matter of national importance and is now one of the most painful problems in the social security system for people with disabilities. Based on a survey of foreign architects, 
as well as in the future development of a barrier-free environment in the context of transport services, we can formulate several main groups of problem situations that prevent the use of people with a limited number of public transport:

Automatic delivery services include various vending machines, ATMs, city telephone systems, mailboxes and various security checkpoints. All of these benefits must be tailored to the needs of people with disabilities. For this group, there are so many named road safety elements - «safety buttons», which are very good security systems [3].

Location for automated services in a barrier-free urban environment depends on the location of target objects - public buildings and structures, recreation areas, pedestrian crossings and traffic flows, public transport stops. In this case, considerations of vandalism and security of facilities play an important role.

- systems of vertical communication devices and lifting devices. These include special stairs, ramps, railings and handrails, the parameters of which correspond to the ergonomics of the aging body. Lifting equipment includes elevators, mobile platforms, elevators, escalators, escalators [4].

The study does not include the development of parameters of these devices, since they are considered sufficient [5.6]. The goal is to place these elements in the structure of the barrier-free structure of the big city. The position of vertical communication device systems is understood because they are are located in places with a difference in relief level or floor level. In this case, the US experience is indicative when inconvenience arises in the form of repair or construction on ordinary tourist routes, vertical roads are arranged, which are temporary in nature (ramps, sidewalks, elevators) [7].

The most important point, as already mentioned, is the broadcasting system. Placement of this system in the structure of a barrier-free urban framework should be universal, but be arranged in such a way as not to interfere with the movement or perception of other objects.

The principles of forming a barrier-free urban environment for people with disabilities are formulated, which determine the characteristics and nature of the equipment of urban spaces for people with disabilities in the urban environment. These include:

- principles from «frame on frame»;

- principle of transport comfort and barrier-free space of technical equipment;

- the principle of «alarm system», providing visual communication;

- the principle of barrier-free organization of the landscape and formation of an environment with special small architectural forms.

The solution to these challenges should be comprehensive and take into account the requirement of continuity of an accessible environment at all urban levels. In this context, the author answered each of the questions in real design and offered basic recommendations on the methodology for the reconstruction of the urban environment in order to turn it into a barrier-free space. 


\section{References:}

1. Строительные нормы республики Казахстан СН РК 3.06-01-2011 Доступность зданий и сооружений для маломобильных групn / Accessibility of buildings and structures for physically and handicapped person - URL: https://online.zakon.kz/Document/?doc_id=37761798\#pos=1;-65.

2. Азаренкова 3.В. Безбарьерная среда для инвалидов в городе. Обзор [Текст]/ 3.В. Азаренкова. - М.: ГУП ЦПП, 2001. - 38c.: ил. 3. СП 59.13330.2016 Свод правил / доступность зданий и сооружений для маломобильных групп населения / Accessibility of buildings and structures for persons with reduced mobility. - URL: http://docs.cntd.ru/document/456033921

4. Коган Л.Б. Сочиальная жизнь города и формирование планировочных структурных единии: автореф. дисс. ... канд. арх.; МАРХИ. - М., 1968.

5. Пособие по проектированию окружающей среды для людей с физическими ограничениями. Bып. 1-2-3[Текст]. - М., 2006.

6. Мурзагалиева Э.Т., Абдрасилова Г.С. К вопросу об адаптации архитектурнопространственной среды для людей с ограниченными возможностями// «Вестник КазГАСА». - Алматы, 2013. - №4 (48) - C. 45-45.

7. Хачатряни К.К. Проблема создания городской среды, доступной для лиц с ограниченными возможностями // Градостроительство и архитектура: актуальные проблемы: Сб. науч. тр./ БНТУ, АФ. Мн.: Тэхналогія, - Беларусь, 2002. - С. 182-185.

8. Рунге В.Ф., Манусевич Ю.П. Эргономика в дизайне среды. - М.: Архитектура - С, 2007.

9. Андреева Г.М. Идентичность с окружающей средой // Психология социальных ситуаџий/ Сост. и общ. ред. Н.В. Гришиной. - СПб.: Питер, 2001. - С. 248-257.

Мақ̧алада құалальқ кеңістіктер жүйесінде кедергісіз ортаны құру проблемалары талқыланып, «кадрва кадр» құавидаты қ̧арастырылады.

Түйін сөздер: кедергісіз орта, құолжетімді орта, мүгедектер, құалалық орта, өмір сүру ортасы.

В статье рассматриваются проблемы создания безбарьерной среды в системе городских пространств, а также принции «каркас на каркасе».

Ключевые слова: безбарьерная среда, доступная среда, люди с ограниченными возможностями, городская среда, жилая среда. 